Brandeis | urear

brandeis.edu/j-caste
CASTE: A Global Journal on Social Exclusion

Vol. 2 No. I pp. 77-96

April 2021

ISSN 2639-4928

DOI: $10.26812 /$ caste.v2i1.260

\title{
Hate Speech against Dalits on Social Media: Would a Penny Sparrow be Prosecuted in India for Online Hate Speech?
}

\author{
Devanshu Sajlan'
}

\begin{abstract}
This article analyzes the Indian hate speech law from the perspective of social media. Recent research shows extensive use of caste-based hate speech on Facebook, including derogatory references to caste-based occupations such as manual scavenging. This article attempts to examine whether the Scheduled castes/Scheduled Tribes (SC/ST) Prevention of Atrocities Act is equipped to deal with online hate speech against Dalits. The jurisprudence around the applicability of Atrocities Act to caste-based hate speech has been analyzed. After the said analysis, the applicability of 'International Convention on the Elimination of All Forms of Racial Discrimination (ICERD)' to castebased discrimination has been studied. Thereafter, the standard of proof for prosecuting hate speech under Indian domestic law has been compared with ICERD to analyze whether Indian domestic law is in compliance with international standards. The article further analyzes whether caste-based hate speech ought to be regulated only when there is incitement to violence or hatred, or it can also be regulated when it violates the right to dignity of Dalits. At the same time, the article also briefly examines whether such prosecution would be in violation of global free-speech standards.
\end{abstract}

\section{Keywords}

Caste-based hate speech, SC/ST Prevention of Atrocities (PoA) Act, ICERD, descent, racial superiority, dignity, incitement to violence or hatred

'Metropolitan Magistrate/ Civil Judge, Delhi Judicial Services Email: devanshu.sajlan26@gmail.com

(C) 202I Devanshu Sajlan. This is an open access article distributed under the terms of the Creative Commons Attribution License, which permits unrestricted use, distribution, and reproduction in any medium, provided the original author(s) and source are credited. 


\section{Introduction}

Dr. Ambedkar, in his famous speech Annihilation of Caste, has provided a detailed account of discrimination and humiliation faced by untouchables ${ }^{1}$ in their daily lives (Ambedkar, 1979; originally 1936, Vol. 1, pp. 23-96). He recounts various such instances spanning hundreds of years: (i) untouchables were not allowed to use public streets during the rule of the Peshwas in the Maratha country, as the mere shadow of an untouchable was considered to be polluting, (ii) In Poona, the capital of Marathas, untouchables were forced to tie a broom around their waists, in order to ensure that the dust, which becomes polluted when an untouchable steps on it, is swept away, (iii) In 1928, an untouchable community in Indore (Balais) was informed that if they wished to live along with the upper-castes, they must not wear fancy clothes and must adhere to the dress code fixed for them by the upper-castes (Ibid, pp. 39-40).

A large section of the society is of the opinion that such instances of humiliation are non-existent today. However, such beliefs could not be farther from the truth. With each passing year, more ingenuous methods have been invented to humiliate Dalits. For example, as recent as July 2020, a 14-year-old Dalit child was forced to eat his own faeces by a person from a dominant caste (Bharathi, 2020).

The statistics also provide a limpid image about the reality of crimes against Dalits. In 2018, a total of 42,539 crimes were reported under the Scheduled Castes and Scheduled Tribes (Prevention of Atrocities) Act, 1989 (Atrocities Act, 1989) (Indiastat, 2018c). It may be noted, for some perspective, that 47,028 cases of hitand-run were reported in 2018 (Indiastat, 2018a). Therefore, crimes against Dalits are as pervasive as hit-and-run cases in India, and anybody who believes otherwise is blissfully ignorant.

Unfortunately, the practice of attacking the dignity of Dalits has now found a new medium. A recent study has concluded that thirteen percent posts having hate content on Facebook India pertain to caste-based hate speech, including 'caste-based slurs, derogatory references to caste-based occupations such as manual scavenging, antiAmbedkar posts ...' (Soundararajan et al., 2019, p. 40). Figures 1 and 2, highlighted below, are a clear illustration of online hate speech against Dalits.

The question that naturally arises is whether there exists any legal remedy against online caste-based hate speech? There exists an interesting parallel from South Africa, where a woman named Penny Sparrow was prosecuted for a racist rant on Facebook, in which she compared the Black community with monkeys (ANC v. Penny Sparrow, 2016, p. 33). The Equality Court ${ }^{2}$ found Penny Sparrow guilty of hate speech under

\footnotetext{
'In this article, the terms 'Untouchable', 'Scheduled Caste' (SC) and 'Dalit' have been used inter-changeably depending on the context. Untouchability can be broadly defined as a social practice whereby persons, merely by virtue of birth in a certain community, are considered perpetually polluted, and social norms prohibit any kind of contact with the said community. The said practice, the genesis of which is the caste system, has perpetuated social exclusion and exploitation of the untouchable community. For an understanding of the relation between caste system and the exploitation of the untouchable community, see Ambedkar (1979; originally 1936, pp. 62-63). For a brief history of the origin of untouchability in India, see Mendelsohn \& Vicziany (1998, pp. 1-43); Waughray (2013, pp. 23-29); Keer, (1971, pp. 1-4).

${ }^{2}$ South Africa, to make right to equality more accessible, has created special courts, called Equality Courts, designed to be accessible to all South Africans. These courts hear cases relating to unfair discrimination, harassment, and hate speech (Botha \& Kok, 2019).
} 
Section $10^{3}$ of the Promotion of Equality and Prevention of Unfair Discrimination Act, 2000 (Ibid, p. 52). Would a caste-based slur against Dalits be punishable under Indian law similarly?

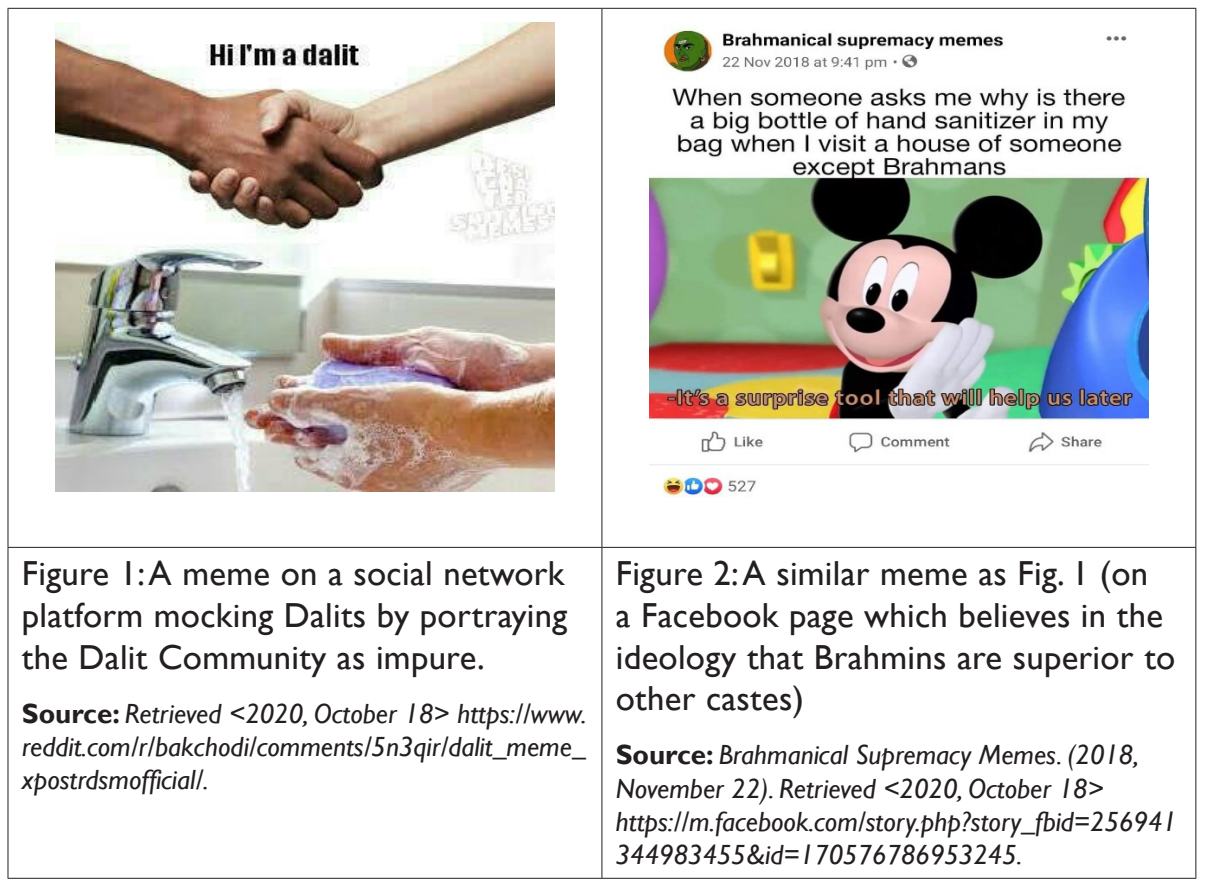

This article analyzes the Indian caste-based hate speech law from an international legal perspective. While comparing Indian 'caste-based hate speech' law with International Convention on the Elimination of All Forms of Racial Discrimination (ICERD), this article attempts to answer two principle questions: (i) whether caste based hate speech ought to be regulated only when there is incitement to violence or hatred, or it can also be regulated when it violates the right to dignity of a marginalized community; and (ii) whether hate speech should also be prosecuted when it is directed against an entire community, as opposed to being directed against particular individuals. The next section discusses the Indian law in relation to caste-based hate speech.

\section{Case Law Precedent: Hate Speech on Facebook}

In 2017, the High Court of Delhi dealt with a case where the complainant had filed a complaint alleging that the accused had continuously harassed her by abusing her caste on Facebook, i.e., the accused boasted that she belonged to the Rajput community and claimed that persons belonging to Dhobi community have no standard of living

\footnotetext{
${ }^{3}$ Section 10(1) provides: No person may publish ... words based on one or more of the 10 prohibited grounds against any person that could reasonably be construed to demonstrate a clear intention to a) be hurtful; b) be harmful or to incite harm and c) promote or propagate hatred. It may be noted that this Section was recently held to be unconstitutional for being vague by the Supreme Court of Appeal of South Africa in Qwelane v. South African Human Rights Commission (2020). This Section has been re-worded in the aforesaid judgment to align it with the right of freedom of speech.
} 
as 'they are cheap people' (Gayatri v. State, 2017, para 4). The complaint had been filed under Section 3(1)(x) ${ }^{4}$ of the Atrocities Act, 1989, which punishes a person who 'intentionally insults or intimidates with intent to humiliate a member of a Scheduled Caste or a Scheduled Tribe' [emphasis added].

The High Court of Delhi noted that section 3(1)(x) requires that the offending statement must be directed against an individual member of SC/ST, and if a statement, instead of being directed against a specific member, is directed against the community as a whole, it would not amount to an offence under section 3(1)(x) (Ibid, para 3738). Therefore, since in the present case, the offending statement was not directed against an individual, and was instead directed against the entire Dhobi community, no offence under section 3(1)(x) was held to be made out (Ibid; see also D.P. Vats $v$. State, 2002, para 9).

When the aforesaid case was filed, the 2016 Amendment Act had not come into effect which introduced a provision, Section 3(1)(u), to punish hate speech against the SC/ST community as a group, as opposed to merely punishing hate speech against an individual member.

However, as discussed next, the standard of proof under section $3(1)(u)$, which applies to group based hate speech, appears to be completely different from the standard of proof under section 3(1)(r) (erstwhile section 3(1)(x)), which applies to hate speech directed at an individual.

\section{Punishing Hate Speech: Violation of Dignity versus Threat to Public Order}

Broadly, there are two categories of hate speech laws, one which protect human dignity, and the other which safeguard threat to public order. ${ }^{5}$ Countries like United Kingdom, Northern Ireland, Israel and Australia have drafted their hate speech laws to safeguard public order (Coliver, 1992, p. 366). For instance, in UK, an insulting speech is punishable only when it has been made to 'stir up racial hatred' (1986 Public Order Act (UK) s. 18(1)(a); see also Ibid, p. 367). On the other hand, the underlying object of hate speech laws of certain countries like Canada, Denmark, Germany, and the Netherlands is to protect human dignity (Coliver, 1992, p. 363).

Considering the aforesaid distinction, this section will analyze the different scope and purpose of section 3(1)(r) and 3(1)(u) of the Atrocities Act, 1989.

\footnotetext{
${ }^{4}$ In July 2015, when the aforesaid complaint was filed, section 3(1)(x) was in force. However, section 3(1) has been substituted by the Amendment Act of 2016 with effect from 26 January 2016. Pursuant to the said amendment, section 3(1)(x) has become section 3(1)(r); however, the wording of the provision has remained the same.

${ }^{5}$ For a definition of 'public order' developed by Indian courts, see Brij Bhushan v. The State of Delhi, 1950; Romesh Thappar v. The State of Madras, 1950; In the Superintendent, Central Prison, Fatehgarh v. Ram Manohar Lohia, 1960; Arun Ghosh v. State of West Bengal, 1970; Kishori Mohan Bera v. The State of West Bengal, 1972; Naripada v. State of West Bengal, 1973; Commissioner of Police v. C. Anita (Smt.), 2004. In India, the term 'public order' has been defined by courts to mean a sense of public peace, safety and tranquility. It is something more than ordinary maintenance of law and order. More specifically, "[w]hile the expression 'law and order' is wider in scope in as much as contravention of law always affects order, 'public order' has a narrower ambit, and public order could be affected by only such contravention which affects the community or the public at large." (Commissioner of Police v. C. Anita (Smt.), 2004, para 7).
} 
Section 3(1)(r) (erstwhile section 3(1)(x)) has been interpreted by the courts in India as protecting the right to dignity of the SC/ST community (Swaran Singh v. State, 2008, para 22, 29; Naval, 2001, p. 83). Therefore, once the victim proves that he/she was intentionally humiliated in public view for the reason that the victim belongs to SC/ST community, there is no additional ingredient requiring proof of disturbance of public order due to the said insulting speech (see Daya Bhatnagar v. State, 2004, para 15). To illustrate, it has been held that use of the term Chamaar 'in a derogatory sense to insult or humiliate a member of SC/ST' would be punishable under Section 3(1)(x) (Swaran Singh v. State, 2008, para 30).

On the other hand, Section 3(1)(u), which applies to hate speech targeted against Dalits as a group, is differently worded as compared to section 3(1)(r) (erstwhile Section 3(1)(x)). While Section 3(1)(r) punishes intentional insult or intimidation of a member of SC/ST community, Section 3(1)(u) punishes promotion of 'feelings of enmity, hatred or ill-will against members of the Scheduled Castes or the Scheduled Tribes' [emphasis added] (Atrocities Amendment Act, 2016, s. 4(i)). At first glance, the phrase 'enmity, hatred or ill-will' appears to be sufficiently broad to cover situations pertaining to violation of dignity and intentional humiliation of members of SC/ST community. However, before such a conclusion can be reached, it is imperative to first scrutinize the jurisprudence interpreting this phrase.

The phrase 'enmity, hatred or ill-will' in Section 3(1)(u), Atrocities Act, 1989 has been borrowed from various other provisions of criminal law in India, for example, Section 153A and 505 (2) of Indian Penal Code, 1860 (IPC). ${ }^{6}$ In relation to the said provisions, this phrase has been interpreted in a restrictive manner by the courts of India in order to balance it with freedom of expression (see Manzar Sayeed Khan $v$. State of Maharashtra, 2007, para 16, Balwant Singh v. State of Punjab, 1995, para 9). To illustrate, it has been held by the Supreme Court of India that:

In our opinion only where the written or spoken words have the tendency or intention of creating public disorder or disturbance of law and order or affect public tranquility, that the law needs to step in to present such an activity ... The intention to cause disorder or incite people to violence is the sine qua non of the offence under Section 153A IPC. [emphasis added] (Balwant Singh v. State of Punjab, 1995, para 9).

Moreover, when the constitutionality of section 153A, IPC was challenged in the Bombay High Court, it noted that the acts causing enmity, hatred or ill-will are 'clearly calculated to disturb public order, and so the limitations imposed by Section 153A are in the interests of public order'; and it was accordingly held that the said actions are clearly within the scope of permissible legislative restrictions on the fundamental right of freedom of expression (Gopal Vinayak Godse v. Union of India, 1969, para 60). Accordingly, it is evident that the courts in India have held that the phrase 'enmity, hatred or ill-will' is actionable only when it is coupled with an 'intention to cause disorder or incite people to violence' (Ibid). ${ }^{7}$

${ }^{6}$ For an understanding of the scope of section 153A and 505 (2), see Arun et al. (2018, pp. 25 31); David (1997, pp. 211-214).

${ }^{7}$ This position of law has been re-iterated by the Supreme Court of India recently in the following words: $[\mathrm{P}]$ enal action would be justified when the speech proceeds beyond and is of the nature which defames, stigmatizes and insults the targeted group provoking violence or psychosocial 
Based on the aforesaid interpretation, it appears that Section 3(1)(u) of the Atrocities Act, 1989, introduced vide the 2016 amendment, will apply in only those situations where an offending statement poses a threat to public order. Accordingly, online hate speech, targeted at the SC/ST community in general, which is meant to violate the dignity of the SC/ST community but does not pose a threat to public order, will not fall foul of Section 3(1)(u).

The next section of this article will analyze whether there is an international obligation on India to prosecute statements which are meant to violate the right to dignity of Dalits as a community.

\section{International Law-ICERD: Applicability to Dalits}

The International Convention on the Elimination of All Forms of Racial Discrimination (ICERD) was adopted by the United Nations General Assembly in 1965 and entered into force in 1969 (ICERD; Shirane, 2011, p. 1). ICERD defines 'racial discrimination' in terms of five parameters, i.e., race, colour, descent, and national or ethnic origin (ICERD art.1, para1; Shirane, 2011, p. 2).

The Committee on the Elimination of Racial Discrimination (CERD) has clarified twice that caste-based discrimination is a form of racial discrimination, since it is covered within the scope of 'descent' (Waughray, 2010). The first such affirmation came in 1996, when CERD, in its concluding observations on India's periodic report in 1996, stated that "the term "descent" ... does not solely refer to race [and] that the situation of the scheduled castes and scheduled tribes falls within the scope of the Convention' (The United Nations, 1996a, para 352). In 2002, this statement was reiterated in the form of a General Recommendation ${ }^{8}$ wherein it was affirmed that "discrimination based on "descent" includes discrimination ... based on forms of social stratification such as caste and analogous systems of inherited status' (CERD, 2002).

\section{Analysis of India's stand on applicability of ICERD to caste-based discrimination}

As opposed to CERD's stance, India has taken a stance internationally that caste-based discrimination is not covered within the scope of racial discrimination under ICERD. While India has accepted that caste is based on descent, since people are normally born into a particular caste, it has maintained that 'descent' in ICERD clearly refers to 'race', which is different from caste (The United Nations, 1996b, para 7). To support this position, Mr. Swashpawan Singh, India's delegate at the 1996 CERD session, made the following arguments:

i. while 'the Indian representatives before the Committee belonged to separate castes, their racial identification was the same' (The United Nations, 1996c, para 38);

ii. '[d] escent was not always traceable through caste as, for instance, in the case of a change of caste through inter-caste marriage' (Ibid, para 39);

hatred. The 'content' should reflect hate which tends to vilify, humiliate and incite hatred or violence against the target group based upon identity of the group beyond and besides the subject matter. [emphasis added] (Amish Devgan v. Union of India, 2020, para 65)

${ }^{8}$ The terms 'General Recommendation' and 'General Comment' are used interchangeably in international law. For a brief understanding about the meaning of General Comments/ Recommendations, see Keller \& Grover (2012, pp. 116-198). 
iii. "concept of "race" in India as recognized under the Constitution was distinct from caste [and] separate references to the two made it clear that caste was not equated with race' (Ibid, para 37).

These arguments have been discussed as follows.

First, racial, or biological identification is not the only criterion for a particular group to be included within the scope of ICERD. Domestic courts in various countries, which are signatories to ICERD, have held that 'racial discrimination' ought not to be interpreted restrictively in strictly biological or racial terms. For instance, in United Kingdom (UK), as early as 1983, the House of Lords had recognized Sikhs to be

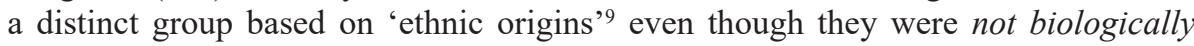
distinguishable from other people living in Punjab (Mandla v. Dowell-Lee, 1983, p. 7; Farkas, 2017, p. 74). The court further noted that 'ethnic origin' (one of the grounds of racial discrimination) must be recognized in a broad cultural/ historic sense, and not on biological distinction merely (Mandla v. Dowell-Lee, 1983, p. 5). Moreover, CERD, in addition to asserting that 'descent' does not solely refer to race, has further iterated that ICERD is a living instrument and it must be 'applied taking into account the circumstances of contemporary society' (CERD, 2009; Stephen Hagan v. Australia, 2003, para 7.2-7.3; Keane, 2020, pp. 237-240; Waughray, 2013, p. 136). Therefore, ICERD must not be interpreted in a restrictive manner as maintained by India. In fact, domestic courts in UK, through purposive interpretation, have accepted 'ethnic origin' to be wide enough to include caste, in order to ensure compliance with UK's international obligations under ICERD (Tirkey v. Chandok, 2013, para 51, 52).

The second argument related to difficulty in tracing descent through caste in case of an inter-caste marriage also appears to be misconceived. Two issues may exist in relation to an inter-caste marriage: (i) if a Dalit woman marries an upper-caste man, what would be the effect on her caste status post such marriage? (ii) what would be the status of a person, one of whose parents belongs to the SC/ST community, and the other does not? With respect to the first issue, the Bombay High Court has held that a member of SC/ST 'has to suffer from disadvantages, disabilities and indignities' merely by virtue of birth in a particular caste and the said caste label continues notwithstanding marriage with a forward caste person (Rajendra Shrivastava v. State of Maharashtra, 2010, para 12; see also V.V. Giri v. D. Suri Dora, 1959, para 23). Therefore, it is a settled position of law that caste is acquired by descent and does not change by virtue of an inter-caste marriage. Moving on, with respect to the second issue, the Supreme Court has held that normally in an inter-caste marriage, there is a presumption that the child has the caste of the father (Rameshbhai Dabhai Naika v. State of Gujarat, 2012, para 55). However, ultimately, it is a question of fact and the child can lead evidence to show that 'he/she was brought up by the mother who belonged to SC/ST' (Ibid). Therefore, Supreme Court has clarified all issues with respect to traceability of caste in an inter-caste marriage. Moreover, it is evident that courts in India are already dealing with these issues, and there is no additional legal difficulty which will arise by recognizing caste as an aspect of 'racial discrimination', as claimed by the Indian delegation.

9'Ethnic Origin' was defined in this case to be based on cultural and historical factors (and not biological factors):

(1) a long shared history of which the group is conscious as distinguishing it from other groups, and the memory of which it keeps alive (2) a cultural tradition of its own, including family and social customs and manners, often but not necessarily associated with religious observance. (Mandla v. Dowell-Lee, 1983, 562D-H). 
The Indian delegation's third contention was that separate references to 'race' and 'caste' in the Indian constitution made it clear that caste was not equated with race in the country. However, as per the settled position of international law, as recognized under Vienna Convention on the Law of Treaties (VCLT), India cannot invoke the provisions of its domestic law as an excuse to not perform its obligations under ICERD (The United Nations, 1969, art. 27; Villiger, 2009, pp. 370-373). It is a generally accepted principle of international law that the provisions of municipal law cannot be taken as an excuse to not perform the treaty obligations (Ibid). Therefore, the distinction between 'caste' and 'race' under the Indian Constitution cannot be taken as an excuse by India to restrict the scope of 'racial discrimination' as defined under ICERD.

\section{Dr. David Keane: Scope of 'descent'}

In addition to analyzing the stance of Indian delegation with respect to caste, it will be useful to discuss the analysis done by Dr. David Keane (2005), a prominent human rights scholar, in his published work on this issue. Based on the reasons highlighted below, Dr. Keane has argued that 'caste' should not be covered within the scope of 'descent'.

He first notes that 'descent' was introduced in ICERD at India's behest to address the objections raised over the meaning of 'national origin' ${ }^{10}$ (Ibid, p.106). He further notes that apart from this background, there is hardly any discussion regarding the significance and scope of 'descent' in the travaux préparatoires (Ibid, p.108). In light of this, he argues that since 'descent' was included in ICERD at the behest of India, Indian delegation would have certainly made a reference to 'caste' while introducing 'descent', if they intended 'caste' to be included within the scope of 'descent'(Ibid).

In addition to the aforesaid argument, Dr. Keane further argues that the existence of 'descent' in article 16(2) of Constitution of India as a prohibited ground of discrimination, in addition to and separate from 'caste', makes it evident that India did not intend to include 'caste' within the scope of ICERD, since India only introduced 'descent' as a ground of racial discrimination, but not 'caste' (Ibid, pp. 110-114).

While the aforesaid analysis does raise some doubts with respect to the inclusion of 'caste' within the scope of 'descent' under ICERD, there is another way to examine this issue. In his work, Dr. Keane has referred to two kinds of 'supplementary means of interpretation'"1 to interpret the scope of 'descent': (i) negotiation records of ICERD; (ii) internal document of a negotiating party, i.e. the Constitution of India (Keane, 2005, pp. 105-114). These documents are discussed as follows.

With respect to the use of an internal document of a negotiating party as a supplementary means of interpretation, it is a settled position of law that all the treaty parties concerned must be aware of the said document, if it is to be invoked in respect of a treaty's interpretation (Villiger, 2009, p. 446). In case of lack of awareness about

\footnotetext{
${ }^{10}$ The amendment to article 1(1) was introduced by Mr. K.C. Pant during $1299^{\text {th }}$ meeting of UNGA's third committee on 11 October 1965. The official UN records capture the said event in the following manner: 'Introducing his delegation's amendments (A/C.3/L.1216), he explained that the first one, relating to article I, was intended to meet the objections raised by many delegations to the words "national origin".' [emphasis added] (The United Nations, 1965a, para 29).

${ }^{11}$ In international law, in a situation where literal interpretation does not lead to a clear result and leaves the meaning ambiguous or obscure, article 32 of VCLT allows resort to supplementary means of treaty interpretation to determine the true meaning of a term (The United Nations, 1969, art. 32).
} 
the internal document of a negotiating party, the said document cannot be relied upon as a supplementary means of interpretation, since it merely reflects the 'unilateral intent of one party to the negotiations rather than the common intent of all ... parties' (see Canfor Corporation v. The USA, 2004, para 19). Pertinently, while a scrutiny of the drafting history of the Constitution of India suggests that the concept of 'descent' is separate from 'caste' in the Indian Constitution, ${ }^{12}$ the said distinction was not elaborated upon when India introduced 'descent' as a ground of racial discrimination under ICERD. While K.C. Pant, who was part of Indian delegation when India introduced 'descent' in ICERD, did refer to articles 15, 16, and 17 of the Constitution of India, he did so merely to highlight that all forms of discrimination were prohibited in India, and there was no explanation given by him to explain the scope of 'descent' under Indian Constitution (The United Nations, 1965a, para 28). In fact, Dr. Keane (2005) himself notes that 'the significance of the introduction of the word 'descent'... was never alluded to in the debate' (p. 108). Accordingly, the internal document of India, i.e. the Constitution of India, which creates a distinction between 'descent' and 'caste', cannot be relied upon as a supplementary means of interpretation, since it only indicates India's unilateral intent to treat 'descent' separately from 'caste', rather than the common intent of all parties.

Moving on to the next supplementary means of interpretation, i.e. the negotiation records of ICERD, it is indeed true that 'caste' was not mentioned in relation to discussions around article 1(1), which defines 'racial discrimination' (Keane, 2005, p. 108). However, 'caste' was mentioned by an Indian delegate during the drafting negotiations around articles 1(4) and 2(2), which were proposed to be inserted to allow temporary special measures for the development of certain racial groups (The United Nations, 1965b, para 24-25). It is difficult to imagine why India would want to request for allowing special provisions for SC/ST community if they were otherwise not covered within the scope of ICERD.

Moreover, while it has been argued by Dr. Keane that there is no indication in the negotiation records to point towards the inclusion of 'caste' within the scope of 'descent', the converse is also equally true, i.e., there is no indication in the negotiation records to point towards the exclusion of 'caste' from the purview of 'descent'. The negotiation records are silent either way, and it is difficult to infer the scope of 'descent' from the same.

\section{Significance of CERD General Recommendations}

Based on the aforesaid discussion, it is evident that ICERD's travaux préparatoires do not provide much information about the intended scope of 'descent'. However, just because there is ambiguity arising from the reading of travaux préparatoires, 'descent' cannot be left to have no meaning at all in ICERD. ${ }^{13} \mathrm{~A}$ fundamental principle of treaty interpretation is based on the latin maxim ut res magis valeat quam pereat (the principle of effectiveness), which requires that treaty interpreters must give meaning and effect

\footnotetext{
${ }^{12}$ The drafting history of article 15 and 16 of the Constitution of India indicates that 'descent' was introduced as a separate ground from 'caste' in article 16 (see Rao et al. (1967, Vol. 2, pp. 289-290). See also Keane (2005, pp. 110-114). For further context regarding the scope of 'descent' under Indian Constitution, see the discussion on amendment Nos. 280, 282 and 279 in Constituent Assembly Debates, Vol. VII, http://164.100.47.194/Loksabha/Debates/ cadebatefiles/C29111948.html. [https://perma.cc/FT6N-P7BU].

${ }^{13} \mathrm{Dr}$. Keane, after discussing the travaux préparatoires of ICERD, cites some commentators who have opined that 'descent' may not have any particular meaning in article 1(1) of ICERD since there is lack of clarity around the situations it was intended to cover (Keane, 2005, p. 110).
} 
to all the terms of a provision (US Gasoline, 1996, p. 23; Chile - Price Band, 2002, para 7.71; International Commission of Inquiry on Darfur, 2005, para 494; Georgia v. Russian Federation, 2011, para 133-134; Dörr \& Schmalenbach, 2012, p. 35). Based on the principle of effectiveness, an interpreter must not adopt a reading that would result in making a substantial part of a provision redundant. Therefore, it is imperative to interpret article 1(1) of ICERD in such a manner that all the terms of the article are given their maximum effect.

Once the travaux préparatoires fail to provide the true meaning of a provision, it becomes necessary to turn to other supplementary means to give effect to all the terms of the said provision. This is where the role of General Recommendations passed by CERD becomes crucial. General Comments/ Recommendations have been accepted by various commentators to be authoritative interpretations of rights and duties contained in international treaties (Craven, 1995, p. 91; Scheinin, 1997, p. 444; Dommen, 1998 , p. 8; Byrnes, 1988-1989, p. 216). There are various international documents where General Comments have been stated to be authoritative in nature (Mechlem, 2009, p. 930). ${ }^{14}$

In addition to being recognized as an authoritative interpretative source, General Comments have also been understood to be a useful form of supplementary means of interpretation by International Law Association (ILA) (ILA Interim Report, 2002, p. 14; ILA Final Report, 2004, pp. 5-6). ${ }^{15}$

Therefore, General Comments are a useful means of interpretation, especially when the meaning of a treaty provision is unclear after applying other sources of treaty interpretation. Considering the aforesaid position of law, particular emphasis needs to be placed on CERD General Recommendation 29, which, as highlighted earlier in this Article, affirms that discrimination based on 'descent' includes discrimination based on 'caste' (CERD, 2002). In light of CERD's position on caste based discrimination, domestic courts in UK, as highlighted above, have already accepted 'caste' to be covered within the scope of 'ethnic origin', to ensure compliance with UK's international obligations under ICERD (Tirkey v. Chandok, 2013, para 51, 52). Consequently, considering the aforesaid discussion, India should also recognize 'caste-based discrimination' as a form of 'racial discrimination', by recognizing 'caste' within the scope of 'descent' or 'ethnic origin'.

\section{ICERD: Case Laws in Relation to Prohibition on Dissemination of Ideas Based on Racial Superiority or Hatred}

The previous section of this article has established that 'caste' is covered within the definition of 'racial discrimination' in ICERD. Accordingly, India's legislation on caste-based discrimination is required to comply with ICERD.

\footnotetext{
${ }^{14}$ For instance, the UN Commission on Human Rights has stated in one of its reports that: 'The implementation ... should be guided by General Comment 12 ... which was an authoritative legal interpretation clarifying the normative content of the right and the respective State obligations' [emphasis added] (The United Nations, 2001, para 14; see also The United Nations, 2000, para 58).

${ }^{15}$ While there may be lack of clarity on the exact status of General Comments as a source of interpretation, recent research on this subject has suggested that:

[A]t a minimum, good faith interpretation ... as required by article 31(1) of the Vienna Convention, obliges states parties to duly consider the content of General Comments, as they are the product of a body established by states parties to interpret the Covenant ... (Keller \& Grover, 2012, p. 129)
} 
The next step is to find out whether there is any obligation under ICERD to prosecute hate speech which is directed against an entire community (as opposed to individuals). The relevant provision in this regard is article 4(a), ICERD which prescribes punishment for four categories of transgression: (i) dissemination of ideas based upon racial superiority or hatred; (ii) incitement to racial hatred; (iii) acts of violence against any race or group of persons of another colour or ethnic origin; and (iv) provision of any assistance to racist activities, including their financing (ICERD art. 4, para (a); Shirane, 2011, p. 8).

Two case laws related to article 4(a), ICERD are relevant for the present discussion, which deal with the following two issues: (i) Whether it is possible to prosecute racially discriminative statements under ICERD directed against an entire community (and not against particular individuals); and (ii) Whether there is a condition--precedent requiring 'intention to cause disorder or incite people to violence' for racially discriminative statements to be prosecuted under article 4(a), ICERD.

\section{The Jewish Community of Oslo et al. v. Norway}

In the first case, brought before CERD by the leaders of Jewish Community in Oslo (Norway), the central issue at stake was whether the Jewish community could claim protection against antisemitic speech under article 4, ICERD (The Jewish Community of Oslo et al. v. Norway, 2005, para 3.2). Brief facts of this case are that in 2000, a group (the Bootboys) coordinated a march in remembrance of the Nazi leader Rudolf Hess (Ibid, para 2.1). The leader of the march praised Adolf Hitler and Rudolf Hess for their 'brave attempt to save Germany and Europe from Bolshevism and Jewry during the Second World War' [emphasis added] (Ibid). He further accused the Jews of plundering and destroying Norway by drying up the wealth of the country and disseminating 'immoral and un-Norwegian thoughts' (Ibid).

When the matter was brought before CERD, the first issue was whether Jewish organizations (and not individuals) could claim to be 'victims' within the purview of ICERD (Ibid, para 3.1-3.4). CERD categorically held that article 14 of ICERD allows 'groups of individuals' to file complaints and there is no requirement that each individual within that group be individually a victim of an alleged violation (Ibid, para 7.4). Thus, the complaints filed by Jewish groups/ organizations were found to be maintainable.

What is important to note here is that in The Jewish Community of Oslo et al. v. Norway (2005), the offending speech was not directed against a particular individual. It was directed at the entire Jewish community residing in Norway. CERD noted that there is no requirement for individuals to be hurt personally. Therefore, 'group of individuals' were found to be capable of filing a complaint under ICERD, whenever there is a violation of article 4, ICERD. However, in India, section 3(1)(r) of the Atrocities Act requires that the offending statement must be directed against an individual member of SC/ST, and if a statement, instead of being directed against a specific member, is directed against the community as a whole, it would not amount to an offence. Therefore, section 3(1)(r), Atrocities Act is in variance with the position of law under ICERD.

\section{TBB-Turkish Union in Berlin / Brandenburg v. Germany}

In the second case, the central issue was whether a racially discriminative statement, which was incapable of disturbing public peace or inciting racial hatred, is still 
required to be punished in order to comply with article 4(a), ICERD (TBB-Turkish Union in Berlin/Brandenburg v. Germany, 2010, para 10.1-10.2). The case concerned an interview given by former Finance Senator of the Berlin Senate, Mr Thilo Sarrazin, in a journal in which he made certain derogatory statements against the Turkish population in Germany, including stating that ' 70 percent of the Turkish and 90 percent of the Arab population in Berlin' does not do any work, lives off state resources, does not educate their children, and 'constantly produces new little headscarf girls' (Ibid, para 2.1).

When the matter was brought before CERD, the state party (Germany) argued that in order to balance freedom of expression against the necessity to combat racism, it is necessary to assess whether the relevant act is capable of disturbing public peace (Ibid, para 10.1-10.2). However, CERD opined that Germany had erroneously focused on whether the offending statements were capable of disturbing public peace, since article 4, ICERD did not have any such condition-precedent for prosecuting racially discriminative statements (Ibid, para 12.8; Senier, 2013, p. 893). ${ }^{16}$

Thus, CERD has categorically opined that once a statement is found to be disseminating ideas of racial superiority, it ought to be prosecuted and there is no added requirement of proof of disturbance of public peace. Based on the aforesaid decision, it can be concluded that section 3(1)(u), Atrocities Act, which requires 'intention to cause disorder or incite people to violence' as a condition-precedent for prosecuting hate speech against the SC/ST community, is not in conformity with article 4(a), ICERD.

Therefore, there is a need to interpret section 3(1)(u), Atrocities Act in such a manner that incitement to violence/ hatred is not a requirement for prosecution of hate speech based on caste superiority. The following section analyzes whether prosecution of hate speech in absence of incitement to violence or hatred is against global freespeech standards.

\section{Atrocities Act: Conflict with Global Free Speech Standards}

While the focus of this Article is to compare the Indian law on hate speech with ICERD, this section briefly discusses free speech issues surrounding the prosecution of caste-based hate speech.

In the previous section, it has been argued that there is a need to interpret Atrocities Act in consonance with article 4(a), ICERD. It is evident that ICERD prosecutes racially discriminative statements even in those scenarios where there is no incitement to hatred or violence. Earlier in this Article, it has been observed that while under Section 3(1)(u), Atrocities Act, there is an additional ingredient requiring proof of incitement to hatred or violence, there is no such requirement under Section 3(1)(r).

\footnotetext{
${ }^{16}$ CERD member Carlos Manuel Va'zquez gave a dissenting opinion in this matter. With respect to the issue of requirement of disturbance of peace, Va'zquez observed that article 4, ICERD is "unusual ... in referring to the penalization of speech without an express link to the possibility that such speech will incite hatred or violence or discrimination" (TBB Dissenting Opinion, para 5). He further opined that the absence of this link brings CERD in conflict with the UDHR, and the said conflict was attempted to be resolved by inserting the "due regard" clause in article 4. Considering the said "due regard" clause, Va'zquez opined that there is a need to read "racial superiority' narrowly, to safeguard the free exchange of opinions and ideas on matters of public concern (Ibid).
} 
Similarly, if section $3(1)(\mathrm{u})$ is also interpreted to not require 'incitement to hatred or violence', would there be a potential conflict with free speech standards?

By prosecuting statements intended to humiliate individuals belonging to SC / ST community, without any consequent need to establish incitement to violence or hatred, section 3(1)(r), Atrocities Act has attracted the wrath of various advocates of free speech, who deem the said provision to be extremely broad (Pen International, 2015, p. 31; Human Rights Watch, 2016, pp. 68-69). Human Rights Watch, in its 2016 report, Stifling dissent: The criminalization of peaceful expression in India, stated that 'disrespectful speech, or expression that promotes negative feelings, however offensive, is not the same as incitement to acts of hostility, discrimination, or violence, and as such should not be subject to criminal penalty'; thereby implying that a statement cannot amount to 'hate speech' unless there is incitement to acts of hostility, discrimination, or violence (p. 69).

Moreover, under International law, based on the cumulative reading of articles 19 and 20 of International Covenant on Civil and Political Rights, free speech advocates, like ARTICLE 19 (a United Kingdom-based organization that highlights issues related to free expression), also argue that right to freedom of expression must be restricted only when a statement constitutes incitement to discrimination, hostility or violence (ARTICLE 19, 2012, pp. 21-22, 26).

\section{CERD: Lower level of protection to racist hate speech as compared to other forms of free speech}

The aforesaid issue had cropped up during the drafting of article 4(a), ICERD as well. One of the earlier drafts of article 4, ICERD, proposed punishing only those acts of racial discrimination which led to 'incitement to racial discrimination resulting in acts of violence as well as all acts of violence or incitement to such acts' (The United Nations, 1965c; Partsch, 1992, p. 24). However, in one of the subsequent drafts, it was proposed to declare punishable 'dissemination of ideas and doctrines based on racial superiority or hatred' without regard to violence (The United Nations, 1965d; Partsch, 1992 , p. 24). In light of some apprehensions that such a provision will adversely affect fundamental human rights, it was decided to insert the 'due-regard' clause which provided that State parties' obligations under article 4 (including prosecuting dissemination of ideas based on racial superiority) are to be exercised 'with due regard to the principles embodied in the Universal Declaration of Human Rights and the rights expressly set forth in article 5 of this Convention' (The United Nations, 1965e; Partsch, 1992, p. 24).

Now, while it is evident that the due-regard clause was inserted to balance freedom of expression and the right against racial discrimination, it is essential to keep in mind that ICERD consciously moved away from the pre-condition of 'incitement to violence' for prosecuting acts of racial discrimination. Over the years, CERD has re-iterated this stance. For instance, CERD's General Recommendation 15 unambiguously asserts that the prohibition of all ideas based upon racial superiority or hatred is compatible with the right to freedom of opinion and expression (CERD, 1993, para 4). The reason for the same is simple: freedom of speech, as enshrined in international conventions, is afforded lower protection when used for racist hate speech (The Jewish Community of Oslo et al. v. Norway, 2005, para 10.5). 


\section{Racist hate speech: non-fulfillment of values of free speech}

The reason for providing lower level of protection to racist speech can be gathered from the published work of famous legal scholar and critical race theorist, Richard Delgado. In his famous work published in 1982, titled Words that wound: a tort action for racial insults, epithets, and name-calling, Delgado cited the following categories of free speech values and proceeded to showcase how racist speech does not possess or fulfill any of the said values:

i. Value 1: individual self-fulfillment/expression Delgado argued that instead of being a form of self-expression, racial insult is essentially an attempt to injure by using words. Further, it stifles, rather than furthers, the moral and social growth of the individual who harbors it (1982, pp. 175-176).

ii. Value 2: ascertainment of the truth Delgado contended that since racial insults do not invite any discourse, they are not intended to inform or convince the listener. Therefore, the free speech goal of attainment of truth and taking the best decisions on matters of interest to all is not possible through dissemination of racist speech (Ibid, pp. 176-177).

iii. Value 3: securing participation of the members of society in social and political decision making Delgado described racist hate speech as constituting 'badges and incidents of slavery.' He argued that instead of facilitating wide participation, racist speech helps in the creation of a graded society in which the right to express opinions is restricted to the dominant race (Ibid, p. 178).

iv. Value 4: maintaining the balance between stability and change Since suppression of speech can lead to rigidity in the society, it is important to ensure dissemination of ideas freely to ensure social change and justice is not delayed (Ibid, p. 178). However, Delgado argued that since racism excludes minorities from participating in the contemplation of public issues, it leaves the victims of racism demoralized and unable to fight for social change (Ibid, p. 179). Further, racist speech leads to creation of a system which is indifferent towards the plight of the victims of racism, thereby eliminating any chance of social change in favor of the victims of racism (Ibid).

In addition to showcasing that racist speech does not possess values of free speech, Delgado has further aptly analyzed the negative 'psychological, sociological, and political effects of racial insults' (Ibid, pp. 135-149). Therefore, considering the aforesaid cogent reasons, lower level of protection afforded to racist hate speech cannot be faulted.

\section{Racial discrimination and caste based discrimination: violation of dignity}

In addition to the reasons discussed above, recent research has recognized that racist hate speech undermines the dignity ${ }^{17}$ of its targets, thereby undermining the basic recognition which racial minorities are entitled to (Waldron, J., 2012). It is imperative to remember that the right to dignity is a sacred right inherent in human beings. It has an important place in a democratic society. In fact, the German Constitutional

\footnotetext{
${ }^{17}$ Waldron argues that hate speech undermines 'dignity' of individuals. Waldron defines dignity as people's social and legal status which entitles them to be treated as equals in the ordinary operations of society.
} 
Court has held that human dignity cannot be balanced and must trump every other right available to human beings (Oxford Pro Bono Publico, 2012, p. 26; Enders, 2018, pp. 25-26). Further, the Supreme Court of India has held that right to dignity will trump freedom of speech when a work conveys no message but only amounts to 'a disgusting combination of lewd acts and words whose only effect is to debase, insult, and ridicule the person portrayed' (Devidas Ramachandra Tuljapurkar v. State of Maharashtra, 2015). Therefore, since racist hate speech violates the right to dignity of racial minorities, and conveys no real message, it must be afforded a lower level of protection when compared to other forms of free speech.

Since caste-based hate speech is a form of racial discrimination (as discussed above), it is also liable to a lower level of protection as far as freedom of speech is concerned. It is pertinent to remember that the object behind the enactment of the Atrocities Act is to protect the right to dignity of the SC/ST community (Swaran Singh v. State, 2008, para 22, 29; Naval, 2001, p. 83). Therefore, it is evident that the intent behind the Atrocities Act is to give primacy to the right to dignity of the Dalits.

Moreover, Delgado's analysis with respect to negative psychological, sociological, and political effects of racial insults applies with equal force to caste-based discrimination (Naval, 2001, pp. 5-9; Subramanian, 2015; Jadhav et al., 2016). Being similarly placed with racial hate speech, caste-based hate speech needs to be prosecuted with equal force as racial hate speech.

Accordingly, it is incorrect to argue that section 3(1)(r), Atrocities Act violates global free speech standards. Just as CERD does not require 'incitement to hatred or violence' as a pre-condition for prosecuting racial discrimination, section 3(1) (r), Atrocities Act is also justified in prosecuting caste-based discrimination without requiring 'incitement to hatred or violence'. Therefore, it can be concluded that free speech standards will not be violated if section 3(1)(u), Atrocities Act is interpreted to not require 'incitement to hatred or violence' as a precondition for prosecuting caste based hate speech directed towards the Dalit community as a whole.

\section{Conclusion}

The Dalit community's quest for dignity has spanned centuries with little progress. Crimes against the dignity of Dalits have only intensified with time. The latest tool to violate the dignity of Dalits, online hate speech, can have severe negative psychological effect on Dalits, if not regulated imminently. For instance, Kenneth Clark (1989) has observed, '[h] uman beings ... whose daily experience tells them that almost nowhere in society are they respected and granted the ordinary dignity and courtesy accorded to others will, as a matter of course, begin to doubt their own worth' (pp. 63-64).

Currently, casteist bigots have a free hand in using social media as a platform to humiliate Dalits. For instance, the founder of online anti-caste platform 'Ambedkar's Caravan' is regularly attacked by keyboard warriors through caste-based slurs. He has narrated his ordeal thus: 'In the 10 years of running the anti-caste platform Ambedkar's Caravan, I ... have been called ch***r, gutter-cleaner ...' (Attri, 2019). Further, in a research report on online hate speech prepared by 'Equality Labs' (a South Asian technology organization dedicated to ending caste apartheid), it has been highlighted that 'Indian casteist hate speech is part of an ecosystem of violence designed to shame, intimidate, and keep caste oppressed communities from asserting their rights ...' (Soundararajan et al., 2019, p. 40). 
There is an urgent need to regulate caste-based hate speech to ensure that every citizen can enjoy the same degree of dignity in India. Sections 3(1)(r) and 3(1)(u), Atrocities Act are useful tools that can help in the effective regulation of caste-based hate speech on social media. However, the current wording of Section 3(1)(u) seems to suggest that it will only prosecute hate speech if there is a threat to public order. Such an interpretation of section 3(1)(u) will encourage an atmosphere where caste-based slurs, meant to humiliate the Dalit community and violate their dignity, will continue to go unregulated.

The primary reason for regulating caste-based slurs or hate speech directed at the Dalit community ought to be the protection of right to dignity of the Dalits, and not threat to public order. Such a reading of Section 3(1)(u), Atrocities Act will be in consonance with ICERD which prosecutes dissemination of ideas based on racial superiority, without any need for consequent proof of threat to public order. This article has also highlighted that racist speech does not fulfill free speech values, and hence must be afforded a lower level of protection when compared to other forms of free speech. Consequently, since caste-based discrimination is covered within the scope of ICERD, caste-based hate speech must be treated at par with racial hate speech, thereby being provided a lower level of protection, just like racist hate speech. Further, to guard against violation of free speech standards, Indian courts can begin interpreting Atrocities Act in consonance with ICERD, thereby punishing only those statements, which fall within the four categories of transgression provided in article 4(a), ICERD. Such an interpretation will ensure that Indian law does not end up prosecuting mere insults, which do not rise to the level of racial discrimination as defined in article 4(a), ICERD.

At the end of the day, if a Penny Sparrow is prosecuted in South Africa for comparing the Black community with monkeys, a Penny Sparrow must be prosecuted in India too for referring to the Dalit community as gutter cleaners.

\section{References}

Ambedkar, B. R. (1979; originally 1936). Annihilation of caste. In V. Moon (Ed.), Dr. Babasaheb Ambedkar: writings and speeches, vol. 1. Mumbai: Education Department, Government of Maharashtra.

Amish Devgan v. Union of India, 2020, SCC online SC 994.

ANC v. Penny Sparrow, (01/16) [2016] ZAEQC 1. http://www.saflii.org/za/cases/ ZAEQC/2016/1.pdf.

Appellate Body Report. United States - Standards for Reformulated and Conventional Gasoline, WTO Doc. WT/DS2/AB/R (29 April 1996) [US Gasoline, 1996].

Application of the International Convention on the Elimination of All Forms of Racial Discrimination (Georgia v. Russian Federation), Preliminary Objections, Judgment, I.C.J. Reports 2011, p. 70 [Georgia v. Russian Federation, 2011].

ARTICLE 19. (2012). Prohibiting incitement to discrimination, hostility or violence. Retrieved on September 30, 2020 from https://www.refworld.org/docid/50bf56ee2.html

Arun Ghosh v. State of West Bengal, (1970) 1 SCC 98.

Arun, C., Biswas, A., and Sharma, P. (2018). Hate speech laws in India. New Delhi: Centre for Communication Governance, National Law University, Delhi. 
Attri, P. (2019, August 4). Abuses Ambedkar Caravan founder faces everyday: clean my toilet, you belong to gutter. The Print, Retrieved on October 18, 2020 from https:/theprint.in/ opinion/abuses-ambedkar-caravan-founder-faces-every-day-clean-my-toilet-you-belongto-gutter/272009/

Balwant Singh v. State of Punjab, (1995) 3 SCC 214.

Bharathi, S. P. (2020, July 18). TN Dalit family alleges minor was made to carry faeces for defecating in caste Hindu's land. The News Minute, Retrieved on October 16, 2020 from https://www.thenewsminute.com/article/tn-dalit-family-alleges-minor-was-made-carryfaeces-defecating-anothers-land-128971

Botha, L., and Kok, A. (2019). An empirical study of the early cases in the pilot equality courts established in terms of the Promotion of Equality and Prevention of Unfair Discrimination Act 4 of 2000. African Human Rights Law Journal, 19, 317-336.

Brij Bhushan v. The State of Delhi, (1950) SCR 605.

Byrnes, A. (1988-1989). Women, feminism and international human rights law-methodological myopia, fundamental flaws or meaningful marginalisation - some current issues. Australian Year Book of International Law, 12, 205-240.

Canfor Corporation v. The USA, Procedural Order No. 5 of $28^{\text {th }}$ May 2004.

CERD. (1993). General Recommendation No. 15: General recommendation XV on article 4 of the Convention, $42^{\text {nd }}$ session, adopted March 23.

CERD. (2002). General Recommendation No. 29: general recommendation on descent-based discrimination, $61^{\text {st }}$ session, adopted August 22, UN Doc. CERD/C/61/Misc.29/rev.1.

CERD. (2009). General Recommendation No. 32: the meaning and scope of special measures in the ICERD, $75^{\text {th }}$ session, adopted September 24, UN Doc. CERD/C/GC/32.

Clark, K. B. (1989). Dark ghetto: dilemmas of social power. Middletown, Connecticut: Wesleyan University Press.

Coliver, S. (1992). Hate speech laws: do they work? In S. Coliver (Ed.), Striking a balance: hate speech, freedom of expression and non-discrimination (pp. 363-374). London: Article 19 International Centre against Censorship/Human Rights Centre, University of Essex.

Commissioner of Police v. C. Anita (Smt.), (2004) 7 SCC 467.

Craven, M. (1995). The international covenant on economic, social and cultural rights: a perspective on its development. Oxford: Clarendon Press.

D. P. Vats v. State, 2002 (99) DLT 167.

David, T. (1997). Human rights: group defamation, freedom of expressions and the law of nations. Hague: Martinus Nijhoff Publishers.

Daya Bhatnagar v. State, 2004 SCC OnLine Del 33.

Delgado, R. (1982). Words that wound: a tort action for racial insults, epithets, and namecalling. Harvard Civil Rights-Civil Liberties Law Review, 17, 133-181.

Devidas Ramachandra Tuljapurkar v. State of Maharashtra, (2015) 6 SCC 1.

Dommen, C. (1998). Claiming environmental rights: some possibilities offered by the United Nations' human rights mechanisms. Georgetown International Environmental Law Review, $11(1), 1-48$.

Dörr, O., and Schmalenbach, K. (2012). Article 31 - general rule of interpretation. In Dörr, O., and Schmalenbach, K. (Eds.), Vienna convention on the law of treaties: a commentary. Heidelberg/New York: Springer-Verlag Berlin Heidelberg.

Edger, R. (2010). Are hate speech provisions anti-democratic?: an international perspective. American University International Law Review, 26(1), 119-155.

Enders C. (2018). Human dignity in Germany. In P. Becchi and K. Mathis (Eds.), Handbook of human dignity in Europe. Cham, Switzerland: Springer. 
Farkas, L. (2017). The meaning of racial or ethnic origin under EU law: between identity and stereotypes. European Commission.

Gayatri v. State, 2017 SCC OnLine Del 8942.

Gopal Vinayak Godse v. Union of India, 1969 SCC OnLine Bom 88.

Human Rights Watch. (2016). Stifling dissent: the criminalization of peaceful expression in India. Retrieved on October 14, 2020 from https://www.refworld.org/docid/57442ef84.html

International Law Association ILA (2002). Committee on international human rights law and practice, Interim report on the impact of the work of the United Nations human rights treaty bodies on national courts and tribunals, New Delhi Conference (2002). [ILA Interim Report].

- (2004). Committee on international human rights law and practice, Final report on the impact of the findings of the United Nations human rights treaty bodies, Berlin Conference (2004). [ILA Final Report].

In the Superintendent, Central Prison, Fatehgarh v. Ram Manohar Lohia, [1960] SCR 321.

Indiastat. (2018a). Crime head-wise incidence and rate of cognizable crimes (IPC) in India (2015 to 2018). Retrieved on September 29, 2020 from https:/www.indiastat.com/table/ crime-and-law-data/6/incidence-and-rate-of-cognizable-crimes-ipc-under-different-crimeheads-in-states/1067202/1277658/data.aspx

Indiastat. (2018b). State-wise incidence (I), victims (V) and rate (R) of crime/atrocities against scheduled castes in India - Part XIV. Retrieved on September 29, 2020 from http://www. indiastat.com/table/crime-and-law-data/6/incidence-and-rate-of-crimes-committedagainst-scheduled-castes/12772/1341723/data.aspx

Indiastat. (2018c). State-wise incidence (I), victims (V) and rate (R) of crime/atrocities against scheduled castes in India - Part XVI. Retrieved on September 29, 2020 from https:// www.indiastat.com/table/crime-and-law-data/6/incidence-and-rate-of-crimes-committedagainst-scheduled-castes/12772/1341728/data.aspx

International Commission of Inquiry on Darfur. (2005). Report of the International Commission of Inquiry on Darfur to the United Nations Secretary-General (January 25), Retrieved on October 17, 2020 from https://www.un.org/ruleoflaw/files/com_inq_darfur.pdf

Jadhav, S., Mosse, D., and Dostaler, N. (2016). Minds of caste-discrimination and its affects. Anthropology Today, 32(1-2).

Keane, D. (2005). Descent-based discrimination in international law: a legal history. International Journal of Minority and Group Rights, 12(1), 93-116.

Keane, D. (2020). Mapping the international convention on the elimination of all forms of racial discrimination as a living instrument. Human Rights Law Review, 20(2), 236-268.

Keer, D. (1971). Dr. Ambedkar, life and mission (3 ${ }^{\text {rd }}$ ed.). Bombay: Popular Prakashan (ebook).

Keller, H., and Grover, L. (2012). General comments of the human rights committee and their legitimacy. In H. Keller and G. Ulfstein (Eds.), UN human rights treaty bodies: law and legitimacy (Studies on Human Rights Conventions, pp. 116-198). Cambridge: Cambridge University Press. doi:10.1017/CBO9781139047593.005.

Kishori Mohan Bera v. The State of West Bengal, (1972) 3 SCC 845.

Mandla v. Dowell-Lee, [1983] 2 AC 548 (House of Lords).

Manzar Sayeed Khan v. State of Maharashtra, 2007(5) SCC 1.

Mechlem, K. (2009). Treaty bodies and the interpretation of human rights. Vanderbilt Journal of Transnational Law, 42, 905-947.

Mendelsohn, O. and Vicziany, M. (1998). The untouchables: subordination, poverty and the state in modern India. Cambridge: Cambridge University Press.

Naripada v. State of West Bengal, (1973) 4 SCC 43. 
Naval, T. R. (2001). Law of Prevention of Atrocities on the Scheduled Castes and the Scheduled Tribes. New Delhi: Concept Publishing Company.

Oxford Pro Bono Publico. (2012). Comparative hate speech law: memorandum. Retrieved from https://www.law.ox.ac.uk/sites/files/oxlaw/1a._comparative_hate_speech_annex.pdf

Panel Report. (2002). Chile - Price band system and safeguard measures relating to certain agricultural products, WTO Doc. WT/DS207/R (2002) [Chile - Price Band, 2002].

Partsch, K. J. (1992). Racial speech and human rights: article 4 of the convention on the elimination of all forms of racial discrimination. In S. Coliver (Ed.), Striking a balance: hate speech, freedom of expression and non-discrimination (pp. 21-28). London: Article 19 International Centre Against Censorship/Human Rights Centre, University of Essex.

PEN International. (2015). Imposing silence: the use of India's laws to suppress free speech. Retrieved on October 25, 2020 from http://www.pen-international.org/the-india-reportimposing-silence/.

Public Order Act, (1986) 1986 Chapter 64 (UK).

Qwelane v. South African Human Rights Commission, [2020] 1 All SA 325 (SCA).

Rajendra Shrivastava v. State of Maharashtra, 2010 SCC OnLine Bom 116.

Rameshbhai Dabhai Naika v. State of Gujarat, (2012) 3 SCC 400.

Rao, B. S., Menon, V. K. N., Kashyap, Subhash. et al. (1967). The framing of India's constitution: select documents (Vol. 2). New Delhi: Indian Institute of Public Administration.

Romesh Thappar v. The State of Madras, (1950) SCR 594.

Scheduled Castes and Scheduled Tribes (Prevention of Atrocities) Bill, 1989, Bill No. 62 of $1989,8^{\text {th }}$ Lok Sabha, $14^{\text {th }}$ session. (1989).

Scheinin, M. (1997). International mechanisms and procedures for monitoring. In R. Hanski and M. Suksi (Eds.), An introduction to the international protection of human rights: a textbook. Turku: Institute for Human Rights, Åbo Akademi University.

Senier, A. (2013). TBB - Turkish Union in Berlin/Brandenburg v. Germany. The American Journal of International Law, 107(4), 891-898. doi:10.5305/amerjintelaw.107.4.0891.

Shirane, D. (2011). ICERD and CERD: a guide for civil society actors. Geneva: The International Movement against All Forms of Discrimination and Racism.

Soundararajan, T., Kumar, A., Nair, P., and Greely, J. (2019). Facebook India: towards the tipping point of violence caste and religious hate speech. USA: Equality Labs. Retrieved on September 29, 2020 from https://www.equalitylabs.org/s/Facebook_India_Report_ Equality_Labs.pdf.

Stephen Hagan v. Australia, (2003) U.N. Doc. CERD/C/62/D/26/2002.

Subramanian, A. (2015). Making merit: the Indian institutes of technology and the social life of caste. Comparative Studies in Society and History, 57(2), 291-322.

Swaran Singh v. State, (2008) 8 SCC 435.

TBB - Turkish Union in Berlin/Brandenburg v. Germany, (2010) Communication no. 48/2010, UN Doc. CERD/C/82/D/48/2010.

TBB - Turkish Union in Berlin/Brandenburg v. Germany, (2010) Communication no. 48/2010, Individual Opinion of Mr. Carlos Manuel Vazquez, UN Doc. CERD/C/82/3. [TBB Dissenting Opinion].

The Jewish Community of Oslo et al. v. Norway, (2003) Communication no. 30/2003, U.N. Doc. CERD/C/67/D/30/2003.

The United Nations. (1965). General Assembly, International Convention on the Elimination of All Forms of Racial Discrimination. Treaty Series, 660, 195.

The United Nations. (1965a, October 11). General Assembly, Official Records, third committee, $1299^{\text {th }}$ meeting, UN Doc. A/C.3/SR.1299. 
The United Nations. (1965b, October 15). General Assembly, Official Records, third committee, $1306^{\text {th }}$ meeting, UN Doc. A/C.3/SR.1306.

The United Nations. (1965c, June 16). General Assembly, Draft international convention on the elimination of all forms of racial discrimination: note by Secretary General, UN Doc. $\mathrm{A} / 5921$.

The United Nations. (1965d). General Assembly, Draft international convention on the elimination of all forms of racial discrimination: amendment by Czechoslovakia, UN Doc. A/C.3/L.1220.

The United Nations. (1965e, October 22). General Assembly, Official Records, third committee, $1315^{\text {th }}$ meeting, UN Doc. UN Doc. A/C.3/SR.1315.

The United Nations. (1966). General Assembly, International Covenant on Civil and Political Rights. Treaty Series, 999, 171.

The United Nations. (1969). Vienna Convention on the Law of Treaties. Treaty Series, 1155, 331.

The United Nations. (1996a, September 30). General Assembly, Report of the committee on the elimination of racial discrimination, UN Doc. CERD A/51/18.

The United Nations. (1996b. April 29). Committee on the Elimination of Racial Discrimination, Consideration of reports submitted by States parties under article 9 of the conventionfourteenth periodic reports of States parties due in 1996, UN Doc. CERD/C/299/Add.3.

The United Nations. (1996c, November 27). Committee on the Elimination of Racial Discrimination, Summary record of the 1162 nd meeting, UN Doc. CERD/C/SR. 1162.

The United Nations. (2000, January 13). Economic \& Social Council, Commission on Human Rights, The right to food: report of the high commissioner for human rights, UN Doc. E/ CN.4/2000/48.

The United Nations. (2001, March 30). Economic \& Social Council, Commission on Human Rights, The right to food: report on the third expert consultation on the right to food, UN Doc. E/CN.4/2001/148.

Tirkey v. Chandok, (2013) ET/3400174/2013.

V. V. Giri v. D. Suri Dora, (1960) 1 SCR 426.

Villiger, M. (2009). Commentary on the 1969 Vienna convention on the law of treaties. Leiden: Martinus Nijhoff.

Waldron, J. (2012). The harm in hate speech. Cambridge: Harvard University Press.

Waughray, A. (2010). Caste discrimination and minority rights: the case of India's Dalits. International Journal on Minority and Group Rights, 17(2), 327-353.

- (2013). Capturing caste in law: the legal regulation of caste and caste-based discrimination. Doctoral dissertation, University of Liverpool. 